\title{
ОСОБЕННОСТИ БЕЛКОВО-ЛИПИДНОГО СПЕКТРА МЕМБРАН ЭРИТРОЦИТОВ ПРИ ЭКСПЕРИМЕНТАЛЬНОМ ОСТРОМ ДЕСТРУКТИВНОМ ПАНКРЕАТИТЕ В УСЛОВИЯХ АЛКОГОЛЬНОЙ ИНТОКСИКАЦИИ
}

\author{
(С Долгарева С.А. ${ }^{1}$, Бушмина О.Н. ${ }^{l}$, Харченко А.В. ${ }^{2}$, Конопля Н.А. ${ }^{3}$, Сорокин А.В. ${ }^{1}$ \\ ${ }^{1}$ Кафедра биологической химии, ${ }^{2}$ кафедра патологической анатомии, \\ ${ }^{3}$ кафедра оториноларингологии Курского государственного медицинского университета, Курск \\ E-mail: bushminaon@,kursksmu.net
}

В эксперименте изучено содержание и соотношение белков и липидов мембраны эритроцитов на модели острого деструктивного панкреатита на фоне 5-, 30- и 60-дневной интоксикации этанолом. В условиях панкреатита, в большей степени на фоне алкоголизации, пропорционально длительности интоксикации этанолом, выявлены изменения содержания белков, ответственных за структурообразование и стабилизацию мембраны ( $\alpha$ - и $\beta$-спектрин, дематин, анкирин, белок полосы 4.1, паллидин), формообразование и гибкость (актин, тропомиозин), внутриклеточный метаболизм (анионтранспортный белок, глицеральдегид-3-фосфатдегидрогеназа, глутатион-S-трансфераза, белок полосы 4.5) эритроцитов. Установленные нарушения содержания и соотношения липидных фракций, играющих основную роль в упорядочивании белковых макромолекул и метаболизме эритроцитов, наряду с изменениями архитектоники белков, нарушают внутриклеточный метаболизм и функциональные свойства эритроцитов.

Ключевые слова: острый панкреатит, этанол, белки и липиды мембраны эритроцитов.

\section{THE PECULIARITIES OF PROTEIN-LIPID SPECTRUM OF ERYTHROCYTE MEMBRANES IN EXPERIMENTAL ACUTE DESTRUCTIVE PANCREATITIS UNDER THE CONDITIONS OF ALCOHOLIC INTOXICATION \\ Dolgareva S.A. , Bushmina O.N. ${ }^{1}$, Kharchenko A.V. ${ }^{2}$, Konoplya $N . A .{ }^{3}$, Sorokin A.V. ${ }^{1}$}

${ }^{1}$ Department of Biochemistry, ${ }^{2}$ Department of Pathological Anatomy, ${ }^{3}$ Department of Otorhinolaryngology of Kursk State Medical University, Kursk

The experiment studied the content and ratio of proteins and lipids in erythrocyte membrane on the model of acute destructive pancreatitis associated with 5-, 30-and 60-day alcohol intoxication. Under the conditions of pancreatitis, largely against the background of alcohol- associated pancreatitis, the changes in the content of proteins responsible for structurization and stabilization of erythrocyte membrane ( $\alpha$-and $\beta$-spectrin, dematin, ankyrin, band 4.1 protein, pallidin), shaping and flexibility (actin, tropomiozin), and intracellular erythrocyte metabolism (anion-transport protein, glyceraldehyde-3-phosphate dehydrogenase, glutathione-S-transferase, band 4.5 protein) were revealed. The detected disturbances of the content and ratio of the lipid fractions playing the principle role in sequencing proteinaceous macromolecules and erythrocyte metabolism along with the changes in ordonnance of proteins break the intracellular metabolism and functional properties of erythrocytes.

Keywords: acute pancreatitis, ethanol, proteins and lipids of erythrocyte membrane.

Острый панкреатит является одним из наиболее тяжелых хирургических заболеваний с разнообразным спектром осложнений, высокой летальностью и окончательно не решенным диагностическим и лечебным алгоритмом. Кроме того, отмечена отрицательная тенденция в структуре панкреатита - увеличение числа его деструктивных форм $[4,8,16]$.

Хроническая алкогольная интоксикация (ХАИ) и связанные с ней заболевания также являются одной из важных медико-социальных проблем на сегодняшнее время. Головной мозг, поджелудочная железа, печень, мышцы наиболее чувствительны к действию алкоголя. Значительно страдают при острых и хронических отравлениях этанолом сердечно-сосудистая и иммунная системы, последнее вызывает развитие вторичного иммунодефицитного состояния и инфекционные осложнения $[1,2,13,18]$.
Как в экспериментальных, так и в клинических исследованиях показана тесная связь между этанольной интоксикацией и развитием острого панкреатита. Возникающие при длительном приеме алкоголя вторичный иммунный дефицит, снижение защитных иммунных механизмов, присоединение на этом фоне соматической патологии являются ведущими в механизмах формирования терапевтической резистентности при алкоголизме и срыва ремиссий в процессе терапии сформировавшейся зависимости $[5,6,7,11,15$, $16]$.

В последние 15-20 лет исследованиями различных авторов установлена несомненная роль эритроцитов в регуляции различных звеньев гомеостаза не только в условиях нормы, но в первую очередь в условиях патологии, в том числе и при заболеваниях гепатопанкреатобилиарной системы [17]. В то же время практически отсутствуют данные об изменениях структурных ком- 
понентов мембраны эритроцитов при воздействии этанола и остром панкреатите на фоне алкогольной интоксикации

Целью исследования стало изучение содержания белков и липидов мембраны эритроцитов при остром деструктивном панкреатите на фоне алкогольной интоксикации.

\section{МАТЕРИАЛЫ И МЕТОДЫ ИССЛЕДОВАНИЯ}

Исследования проведены на 87 здоровых половозрелых крысах-самцах Вистар массой 150-200 г. Все исследования проводили в одно и то же время суток с 8 до 12 ч. Содержание и забой животных проводили согласно правилам лабораторной практики РФ (приказ МЗ РФ № 267 от 19.06.2003). Кратковременную алкогольную интоксикацию моделировали принудительным внутрижелудочным введением $20 \%$ раствора этанола в дозе 3 мл/кг через 24 часа в течение 5 дней. При ХАИ этанол в такой же дозе вводили через 24 часа в течение 30 или 60 дней (ХАИ-30, ХАИ60). Экспериментальный ОДП вызывали сразу с кратковременным получением этанола или на 25 и 55 сутки после его длительного введения перевязкой протока левой и правой долей поджелудочной железы, с последующей трехкратной через 60 мин стимуляцией прозерином в дозе 0,2 мг/кг. Экспериментальных животных делили на 7 групп по 12-13 особей в каждой: 1-я группа (контрольная) - здоровые крысы; 2-я получала этанол в течение 5 дней; 3-я группа - ОДП и 5-кратное введение этанола; 4-я группа ХАИ-30; 5-я группа - ХАИ-30 и ОДП; 6-я группа ХАИ-60; 7-я группа - ХАИ-60 и ОДП. Забой крыс осуществляли через 24 часа после последнего введения этанола.

Эритроциты получали из 10 мл гепаринизированной крови, для чего ее отстаивали дважды в 10 мМ Na-фосфатном буфере $(\mathrm{pH}=7,4)$, содержащем $0,9 \%$ хлорида натрия и $3 \%$ декстрана Т-500, в течение 30 минут при температуре $37^{\circ} \mathrm{C}$. После этого кровь центрифугировали, после отделения надосадочной жидкости эритроцитарную массу подвергали дополнительной очистке на хроматографической колонке через HBS-целлюлозу. Мембраны эритроцитов выделяли методом G.T. Dodge [23], липиды мембран определяли методом тонкослойной хроматографии [14]. Электрофорез белков проводили в присутствии додецилсульфата натрия в вертикальных пластинах полиакриламидного геля по методу U.K. Laemmli [25], белки окрашивали кумаси голубым R-250.

При статистической обработке данных использовали пакет компьютерных программ Мicrosoft Excel и Statistica 6.0. Для оценки принадлежности количественных признаков к виду рас- пределения использовали тест Шапиро-Уилка. Оценку статистической значимости различий количественных величин осуществляли с использованием критериев Манна-Уитни и Вилкоксона (при сравнении зависимых групп) Среднее значение ненормально распределенных количественных параметров представлены медианой $(\mathrm{Me})$ с межквартальным интервалом $\left(\mathrm{P}_{25} ; \mathrm{P}_{75}\right)$. Статистически значимыми считали различия с $\mathrm{p}<0,05$.

\section{РЕЗУЛЬТАТЫ ИССЛЕДОВАНИЯ И ИХ ОБСУЖДЕНИЕ}

Моделирование ОДП приводило к снижению в мембране эритроцитов экспериментальных животных содержания $\alpha$-спектрина, анкирина, актина, глицеральальдегид-3-фосфатдегидрогеназы (Г-3-ФД) и глутатион-S-трансферазы (Г-S-T) при нормальном уровне остальных исследованных белков. Развитие ОДП на фоне 5-дневного введения этанола дополнительно снижает представительность анионтраспортного белка (АТБ). При ОДП на фоне ХАИ-30, в отличие от кратковременного введения этанола, снижается содержание $\beta$-спектрина, в еще большей степени, Г-S-T, повышается уровень белков полосы 4.1 и 4.5, паллидина, дематина и тропомиозина. Наиболее выраженные изменения белкового спектра мембраны эритроцитов установлены при ОДП на фоне ХАИ-60: по сравнению с ХАИ-30, в еще большей степени, снижена представительность $\alpha$-спектрина, анкирина, актина, Г-S-T и повышено содержание белка полосы 4.1 и тропомиозина (табл. 1).

Развитие ОДП приводит к снижению уровня в мембране эритроцитов фосфатидилхолина (ФХ), фосфатидилэтаноламина (ФЭ), фосфатидилинозитола (ФИ), сфингомиелина (СМ), повышению содержания лизофосфатидилхолина (ЛФХ), холестерола (Х), триацилглицеролов (ТАГ), суммы моно- и диацилглицеролов (МАГ, ДАГ) и неэстерифицированных жирных кислот (НЭЖК), при нормальном содержании фосфатидилсерина (ФС), глицерофосфолипидов (ГФЛ - сумма ЛФХ, ФХ, ФЭ, ФС и ФИ), фосфолипидов (ФЛ - сумма ГФЛ и СМ) и эфиров холестерола (ЭХ). Моделирование ОДП на фоне 5-дневного введения этанола дополнительно снижает уровень ГФЛ, ФЛ, в еще большей степени $Ф \mathrm{X}, \Phi И, \mathrm{CM}$, повышает представительность ЛФХ, Х и НЭЖК. В отличие от кратковременной интоксикации этанолом, развитие ОДП при ХАИ-30 снижает содержание ФС, ниже значений контроля уровень ТАГ и ДАГ+МАГ, повышает ЭХ, в еще большей степени повышает представительность ЛФХ, Х, НЭЖК и снижает СМ. По аналогии с нарушениями спектра белков мембраны эритроцитов наиболее выраженные изменения установлены при ОДП на 
фоне ХАИ-60 в отношении содержания липидов: по сравнению с ХАИ-30, в еще большей степени, снижен уровень ФХ, ФИ, ГФЛ, СМ, ФЛ и повышено содержание ЛФХ, Х и НЭЖК (табл. 2).

Таким образом, в условиях ОДП, в большей степени на фоне алкоголизации, пропорционально длительности интоксикации этанолом, выявлены изменения со стороны периферических белков, ответственных за структурообразование и стабилизацию мембраны эритроцитов ( $\alpha-$ и $\beta$-спектрин, дематин - основные белки цитоскелета, анкирин, белок полосы 4.1, паллидин), формообразование и гибкость мембраны (актин, тропомиозин), интегральных белков, ответственных за внутриклеточный метаболизм (АТБ, Г-З-ФД, Г-S-T, белок полосы 4.5). Установленные нарушения содержания и соотношения липидного спектра, в первую очеред, снижение содержания мембранных ФЛ и СМ, составляющих основу двойного липидного каркаса клеточной мембраны и играющих основную роль в упорядочивании белковых макромолекул и нормальном метаболизме эритроцитов [24], наряду с изменениями архитектоники белков, несомненно изменят внутриклеточный метаболизм и функциональные свойства эритроцитов периферической крови.

Возможной причиной нарушений белковолипидной мембраны эритроцитов при ОДП и ХАИ является интенсификация свободнорадикальных процессов, результатом чего является возрастание их чувствительности к перекисным процессам [9]. Усиление процессов ПОЛ в клеточных мембранах приводит к уплотнению либо деструкции липидного бислоя, увеличению его микровязкости, уменьшению площади белоклипидных контактов, нарушению функциональной активности белков, в том числе ферментов, изменению мембранной проницаемости и поверхностного заряда, нарушению функционального состояния мембранно-рецепторного комплекса [3, 19, 22, 24].

Таблица 1

Содержание белков в мембране эритроцитов при ОДП на фоне интоксикации этанолом (Мe (k25\%; k75\%)

\begin{tabular}{|c|c|c|c|c|c|}
\hline & 1 & 2 & 3 & 4 & 5 \\
\hline Показатели & Контроль & ОДП & $\begin{array}{c}\text { Этанол - } 5 \text { дней } \\
\text { и ОДП }\end{array}$ & $\begin{array}{c}\text { Этанол - } 30 \text { дней } \\
\text { и ОДП }\end{array}$ & $\begin{array}{c}\text { Этанол - } 60 \text { дней } \\
\text { и ОДП }\end{array}$ \\
\hline$\alpha$-спектрин & $\begin{array}{c}108,3 \\
{[103,1 ; 112,3]}\end{array}$ & $\begin{array}{c}91,2^{* 1} \\
{[89,3 ; 94,4]}\end{array}$ & $\begin{array}{c}92,1^{* 1} \\
{[90,3 ; 95,5]}\end{array}$ & $\begin{array}{c}90,4^{* 1} \\
{[87,7 ; 92,5]}\end{array}$ & $\begin{array}{c}82,1^{* 1-4} \\
{[79,3 ; 85,6]}\end{array}$ \\
\hline$\beta$-спектрин & $\begin{array}{c}103,1 \\
{[97,8 ; 106,4]}\end{array}$ & $\begin{array}{c}101,2 \\
{[98,8 ; 103,5]}\end{array}$ & $\begin{array}{c}100,7 \\
{[98,8 ; 103,6]}\end{array}$ & $\begin{array}{c}88,2^{* 1-3} \\
{[85,6 ; 90,1]}\end{array}$ & $\begin{array}{c}86,3^{* 1-3} \\
{[83,2 ; 90,0]}\end{array}$ \\
\hline Анкирин & $\begin{array}{c}89,0 \\
{[85,2 ; 94,1]}\end{array}$ & $\begin{array}{c}81,2^{* 1} \\
{[78,5 ; 85,7]}\end{array}$ & $\begin{array}{c}80,2^{* 1} \\
{[79,5 ; 83,0]}\end{array}$ & $\begin{array}{c}81,2^{* 1} \\
{[78,8 ; 83,0]}\end{array}$ & $\begin{array}{c}75,2^{*-4} \\
{[72,1 ; 78,4]}\end{array}$ \\
\hline АТБ & $\begin{array}{c}171,6 \\
{[170,2 ; 173,3]}\end{array}$ & $\begin{array}{c}173,3 \\
{[170,3 ; 176,9]}\end{array}$ & $\begin{array}{c}162,0^{* 1,2} \\
{[160,9 ; 165,4]}\end{array}$ & $\begin{array}{c}161,8^{* 1,2} \\
{[158,6 ; 163,4]}\end{array}$ & $\begin{array}{c}160,2^{* 1,2} \\
{[157,7 ; 163,1]}\end{array}$ \\
\hline 4.1 & $\begin{array}{c}70,4 \\
{[68,0 ; 72,8]}\end{array}$ & $\begin{array}{c}69,1 \\
{[66,6 ; 72,2]}\end{array}$ & $\begin{array}{c}66,3 \\
{[64,4 ; 70,0]}\end{array}$ & $\begin{array}{c}81,2^{* 1-3} \\
{[77,9 ; 83,7]}\end{array}$ & $\begin{array}{c}88,3^{* 1-4} \\
{[85,5 ; 91,6]}\end{array}$ \\
\hline Паллидин & $\begin{array}{c}92,1 \\
{[89,9 ; 95,0]}\end{array}$ & $\begin{array}{c}89,2 \\
{[85,5 ; 92,3]}\end{array}$ & $\begin{array}{c}89,7 \\
{[86,1 ; 91,8]}\end{array}$ & $\begin{array}{c}102,4^{* 1-3} \\
{[99,3 ; 105,0]}\end{array}$ & $\begin{array}{c}100,1^{* 1-3} \\
{[97,4 ; 103,1]}\end{array}$ \\
\hline 4.5 & $\begin{array}{c}79,8 \\
{[77,1 ; 81,8]}\end{array}$ & $\begin{array}{c}75,0 \\
{[72,1 ; 77,9]}\end{array}$ & $\begin{array}{c}76,2 \\
{[74,4 ; 79,8]}\end{array}$ & $\begin{array}{c}85,4^{* 1-3} \\
{[82,6 ; 87,1]}\end{array}$ & $\begin{array}{c}84,5^{* 1-3} \\
{[81,2 ; 87,5]}\end{array}$ \\
\hline Дематин & $\begin{array}{c}91,2 \\
{[88,5 ; 94,0]}\end{array}$ & $\begin{array}{c}91,1 \\
{[89,8 ; 94,0]}\end{array}$ & $\begin{array}{c}92,5 \\
{[90,8 ; 95,6]}\end{array}$ & $\begin{array}{c}102,3^{*-3} \\
{[99,3 ; 104,8]}\end{array}$ & $\begin{array}{c}104,4^{*-3} \\
{[101,4 ; 107,8]}\end{array}$ \\
\hline Актин & $\begin{array}{c}88,1 \\
{[86,4 ; 90,3]}\end{array}$ & $\begin{array}{c}75,1^{* 1} \\
{[72,8 ; 78,4]}\end{array}$ & $\begin{array}{c}74,1^{* 1} \\
{[72,2 ; 77,4]}\end{array}$ & $\begin{array}{c}75,4^{* 1} \\
{[72,3: 77,8]}\end{array}$ & $\begin{array}{c}69,2^{* 1-4} \\
{[66,5: 72.3]}\end{array}$ \\
\hline Г-3-ФД & $\begin{array}{c}54,3 \\
{[52,5 ; 57,8]}\end{array}$ & $\begin{array}{c}45,2^{* 1} \\
{[42,2 ; 48,3]}\end{array}$ & $\begin{array}{c}47,4^{* 1} \\
{[45,0 ; 50,3]}\end{array}$ & $\begin{array}{c}\left.45,3^{* 1}\right] \\
{[42,3 ; 47,9]}\end{array}$ & $\begin{array}{c}44,0^{* 1} \\
{[41,8 ; 47,1]}\end{array}$ \\
\hline Тропомиозин & $\begin{array}{c}63,7 \\
{[61,8 ; 66,3]}\end{array}$ & $\begin{array}{c}600,7 \\
{[57,7 ; 63,5]}\end{array}$ & $\begin{array}{c}60,4 \\
{[58,7 ; 63,2]}\end{array}$ & $\begin{array}{c}72,3^{* 1} \\
{[68,8 ; 75,0]}\end{array}$ & $\begin{array}{c}85,0^{* 1-4} \\
{[82,6 ; 88,0]}\end{array}$ \\
\hline$\Gamma-\mathrm{S}-\mathrm{T}$ & $\begin{array}{c}61,2 \\
{[58,8 ; 64,1]}\end{array}$ & $\begin{array}{c}52,1^{* 1} \\
{[49,6 ; 55,2]}\end{array}$ & $\begin{array}{c}55,5^{* 1} \\
{[52,4 ; 58,5]}\end{array}$ & $\begin{array}{c}50,2^{* 1-3} \\
{[47,9 ; 53,3]}\end{array}$ & $\begin{array}{c}42,4^{* 1-4} \\
{[39,8 ; 45,2]}\end{array}$ \\
\hline
\end{tabular}

Примечание: В этой и последующей таблице звездочкой отмечены достоверные отличия медиан (р<0,05), в скобках указаны процентили $25 \%$ и $75 \%$; цифры рядом со звездочкой - по отношению к показателям какой группы даны отличия; единицы измерения показателей в таблицах 1 и $2-$ мг\% 
Таблица 2

Содержание липидов в мембране эритроцитов при ОДП на фоне интоксикации этанолом (Me (k25\%; k75\%)

\begin{tabular}{|c|c|c|c|c|c|}
\hline & 1 & 2 & 3 & 4 & 5 \\
\hline Показатели & Контроль & ОДП & $\begin{array}{c}\text { Этанол - } 5 \text { дней } \\
\text { и ОДП }\end{array}$ & $\begin{array}{c}\text { Этанол - } 30 \text { дней } \\
\text { и ОДП }\end{array}$ & $\begin{array}{c}\text { Этанол - } 60 \text { дней } \\
\text { и ОДП }\end{array}$ \\
\hline$\Phi \mathrm{X}$ & $\begin{array}{c}24,0 \\
{[23,0 ; 26,3]}\end{array}$ & $\begin{array}{c}22,8^{* 1} \\
{[20,8 ; 25,7]}\end{array}$ & $\begin{array}{c}21,4^{* 1,2} \\
{[19,6 ; 23,2]} \\
\end{array}$ & $\begin{array}{c}21,5^{* 1,2} \\
{[20,1 ; 23,2]} \\
\end{array}$ & $\begin{array}{c}20,1^{* 1-4} \\
{[18,2 ; 21,6]} \\
\end{array}$ \\
\hline ЛФХ & $\begin{array}{c}3,9 \\
{[3,7 ; 4,2]}\end{array}$ & $\begin{array}{c}4,2^{* 1} \\
{[3,8 ; 4,6]}\end{array}$ & $\begin{array}{c}4,9^{* 1,2} \\
{[3,0 ; 6,8]}\end{array}$ & $\begin{array}{c}5,5^{* 1-3} \\
{[4,8 ; 6,5]}\end{array}$ & $\begin{array}{c}6,2^{* 1-4} \\
{[5,8 ; 6,7]}\end{array}$ \\
\hline ФЭ & $\begin{array}{c}24,6 \\
{[22,3 ; 27,1]}\end{array}$ & $\begin{array}{c}23,0^{* 1} \\
{[20,6 ; 24,8]}\end{array}$ & $\begin{array}{c}23,1^{* 1} \\
{[19,8 ; 25,1]}\end{array}$ & $\begin{array}{c}21,8^{* 1-3} \\
{[20,2 ; 22,8]}\end{array}$ & $\begin{array}{c}21,6^{* 1-3} \\
{[19,5 ; 23,6]}\end{array}$ \\
\hline$\Phi C$ & $\begin{array}{c}19,7 \\
{[19,4 ; 20,0]}\end{array}$ & $\begin{array}{c}18,7 \\
{[16,9 ; 20,4]}\end{array}$ & $\begin{array}{c}18,6 \\
{[18,1 ; 19,8]}\end{array}$ & $\begin{array}{c}18,1^{* 1} \\
{[16,6 ; 18,8]}\end{array}$ & $\begin{array}{c}18,3^{* 1} \\
{[16,9 ; 19,5]}\end{array}$ \\
\hline ФИ & $\begin{array}{c}4,6 \\
{[4,2 ; 5,1]}\end{array}$ & $\begin{array}{c}4,4^{* 1} \\
{[4,1 ; 4,7]}\end{array}$ & $\begin{array}{c}4,1^{* 1,2} \\
{[3,8 ; 4,5]}\end{array}$ & $\begin{array}{c}4,0^{*} 1,2 \\
{[3,7 ; 4,4]}\end{array}$ & $\begin{array}{c}3,3^{* 1-4} \\
{[2,9 ; 3,7]}\end{array}$ \\
\hline ГФЛ & $\begin{array}{c}76,6 \\
{[73,2 ; 79,8]}\end{array}$ & $\begin{array}{c}73,1 \\
{[70,2 ; 75,5]}\end{array}$ & $\begin{array}{c}72,1^{* 1} \\
{[69,8 ; 75,0]}\end{array}$ & $\begin{array}{c}74,5 \\
{[70,2 ; 76,0]}\end{array}$ & $\begin{array}{c}69,5^{* 1-4} \\
{[67,6 ; 71,4]}\end{array}$ \\
\hline $\mathrm{CM}$ & $\begin{array}{c}12,2 \\
{[10,3 ; 14,8]}\end{array}$ & $\begin{array}{c}11,2^{* 1} \\
{[10,0 ; 12,9]}\end{array}$ & $\begin{array}{c}10,4^{* 1,2} \\
{[9,6 ; 11,4]}\end{array}$ & $\begin{array}{c}8,7^{* 1-3} \\
{[7,2 ; 10,2]}\end{array}$ & $\begin{array}{c}7,3^{* 1-4} \\
{[5,8 ; 8,8]}\end{array}$ \\
\hline ФЛ & $\begin{array}{c}88,6 \\
{[82,1 ; 90,4]}\end{array}$ & $\begin{array}{c}84,3 \\
{[80,9 ; 86,5]}\end{array}$ & $\begin{array}{c}82,5^{* 1} \\
{[78,7 ; 85,3]}\end{array}$ & $\begin{array}{c}83,2^{* 1} \\
{[79,6 ; 86,8]}\end{array}$ & $\begin{array}{c}76,8^{* 1-4} \\
{[73,9 ; 78,6]}\end{array}$ \\
\hline $\mathrm{X}$ & $\begin{array}{c}44,8 \\
{[41,6 ; 46,1]}\end{array}$ & $\begin{array}{c}48,0^{* 1} \\
{[45,4 ; 49,8]}\end{array}$ & $\begin{array}{c}50,3^{* 1,2} \\
{[38,8 ; 52,7]}\end{array}$ & $\begin{array}{c}55,1^{* 1-3} \\
{[52,6 ; 57,7]}\end{array}$ & $\begin{array}{c}61,8^{* 1-4} \\
{[58,6 ; 64,4]}\end{array}$ \\
\hline$Э X$ & $\begin{array}{c}40,0 \\
{[37,4 ; 41,7]}\end{array}$ & $\begin{array}{c}39,7 \\
{[37,4 ; 42,0]}\end{array}$ & $\begin{array}{c}40,1 \\
{[37,2 ; 42,5]}\end{array}$ & $\begin{array}{c}44,6^{* 1-3} \\
{[42,3 ; 46,7]}\end{array}$ & $\begin{array}{c}44,1^{* 1-3} \\
{[42,2 ; 46,3]}\end{array}$ \\
\hline ТАГ & $\begin{array}{c}14,5 \\
{[12,5 ; 15,9]}\end{array}$ & $\begin{array}{c}15,9^{* 1} \\
{[13,8 ; 16,7]}\end{array}$ & $\begin{array}{c}16,3^{* 1} \\
{[14,7 ; 17,2]}\end{array}$ & $\begin{array}{c}12,6^{* 1-3} \\
{[11,2 ; 14,1]}\end{array}$ & $\begin{array}{c}12,3^{* 1-3} \\
{[10,7 ; 13,9]}\end{array}$ \\
\hline ДАГ+МАГ & $\begin{array}{c}9,6 \\
{[9,2 ; 10,1]}\end{array}$ & $\begin{array}{c}10,6^{* 1} \\
{[9,7 ; 11,5]}\end{array}$ & $\begin{array}{c}10,6^{* 1} \\
{[7,2 ; 11,1]}\end{array}$ & $\begin{array}{c}8,2^{* 1-3} \\
{[6,8 ; 9,6]}\end{array}$ & $\begin{array}{c}8,3^{* 1-3} \\
{[8,0 ; 8,6]}\end{array}$ \\
\hline НЭЖК & $\begin{array}{c}2,9 \\
{[2,7 ; 3,2]}\end{array}$ & $\begin{array}{c}3,1^{* 1} \\
{[2,8 ; 3,4]}\end{array}$ & $\begin{array}{c}3,4^{* 1,2} \\
{[3,3 ; 3,7]}\end{array}$ & $\begin{array}{c}3,9^{* 1-3} \\
{[3,6 ; 4,3]}\end{array}$ & $\begin{array}{c}4,2^{* 1-4} \\
{[3,8 ; 4,6]}\end{array}$ \\
\hline
\end{tabular}

Кроме этого, при остром панкреатите различной этиологии значительно изменяются структурно-функциональные свойства эритроцитов с изменением, в том числе, и их сорбционной способности $[12,18]$. Сочетание интоксикации этанолом и ОДП усугубляет развитие метаболической иммуносупрессии $[6,11]$ и, что установлено в данной работе, существенно нарушает содержание и соотношение белков и липидов мембраны эритроцитов периферической крови, что в целом может привести к значительно осложненному течению острого панкреатита, развитию осложнений и увеличению смертности.

\section{ЛИТЕРАТУРА / REFERENCES}

1. Алябьева Ф.Б, Крахмаль Н.В., Арбыкин Ю.А., Серебров Т.В., Поверинов С.В., Вогнерубов Р.Н. Морфофункциональные изменения внутренних органов и некоторых биохимических показателей в динамике острой алкогольной интоксикации // Сибирский медицинский журнал (Томск). 2012. - T. 27, № 3. - C. 127-130. [Alyabyev F.V., Krakhmal N.V., Arbykin, Yu.A., Serebrov T.V., Pov- erinov S.N., Vognerubov R.N. The morphofunctional changes in internal organs and biochemical indicators during acute alcohol intoxication. Sibirskiy meditsinskiy zhurnal ( Tomsk). 2012; 27 (3): 127-130 (in Russ.)].

2. Алябьев Ф.В., Серебров Т.В., Кан Т.А., Любина Т.А., Чесалов Н.П., Белоусова О.А., Прибыткова Л.Н., Никулина О.A. Динамика ультраструктурных изменений печени при тяжелой алкогольной интоксикации // Врач-аспирант. - 2017. - Т. 85, № 6. C. 64-68. [Alyabyev F.V., Serebrov T.V., Kan T.A., Lubina T.A., Chesalov N.P., Belousova O.A., Pribytkova L.N., Nikulina O.A. Dynamics of ultrastructural changes of liver due to severe alcohol intoxication. Vrach-aspirant. 2017; 85 (6): 64-68 (in Russ.)].

3. Боровская М.К., Кузнечова Э.Э., Горохова В.Г., Корякина Л.Б., Курильская Т.Е., Пивоваров Ю.И. Структурно-функциональная характеристика мембраны эритроцита и ее изменение при патологиях разного генеза // Бюл. ВСНЦ СО РАМН. - 2010. T. 73, № 3. - C. 334-354. [Borovskaya M.K., Kuznetsov E.E., Gorokhova V.G., Koriakina L.B., Kurilskaya T.E., Pivovarov Ju.I. Structural and functional characteristics of membrane's erythrocyte and its change at pathologies of various genesis. Byulleten' Vostochno-Sibirskogo nauchnogo tsentra Sibirskogo 
otdeleniya Rossiyskoy akademii meditsinskikh nauk. 2010; 73 (3): 334-354 (in Russ.)].

4. Брагов М.Ю., Жук И.Г., Кумова И.В. Острый деструктивный панкреатит: современное состояние проблемы (обзор литературы) // Журнал ГрГМУ. 2007. - T. 20, № 4. - C. 15-19. [Bragov M.Yu., Zhuk I.G., Kumova I.V. Acute destructive pancreatitis: current state of the problem. Zhurnal Grodnenskogo gosudarstvennogo meditsinskogo universiteta. 2007; 20 (4): 15-19 (in Russ.)].

5. Бушиина О.Н., Долгарева С.А., Локтионов А.Л., Конопля А.И. Метаболические нарушения в условиях экспериментального острого деструктивного панкреатита и воздействия этанола // Системный анализ и управление в биомедицинских системax. - 2015. - T. 14, № 3. - C. 396-404. [Bushmina O.N., Dolgareva S.A., Loktionov A.L., Konoplya A.I Metabolic disturbances in the conditions of the experimental acute destructive pancreatitis and influence of ethanol. Sistemnyy analiz i upravleniye v biomeditsinskikh sistemakh. 2015; 14 (3): 396-404 (in Russ.)].

6. Винник Ю.С., Дунаевская С.С., Антюфриева Д.А. Риск развития осложнений при остром алкогольассоциированном панкреатите // Новости хирургии. - 2012. - Т. 20, № 4. - С. 38-41. [Vinnik Yu.S., Dunaevskaya S.S., Antufrieva D.A. Risk of complications development at alcohol-related acute pancreatitis. Novosti Khirurgii. 2012; 20 (4): 38-41 (in Russ.)].

7. Газатов Н.Д., Юрова К.А., Гаврилов Д.В., Литвинова Л.С. Оценка кислородзависимой цитотоксичности фагоцитирующих клеток у больных алкогольным фиброзом печени // Цитокины и воспаление. - 2017. - Т. 16, № 3. - C. 33-35. [Gazatova N.D., Yurova K.A., Gavrilov D.V., Litvinova L.S. Assessment of oxygen-dependent cytotoxicity of phagocytic cells from patients with alcoholic fibrosis of the liver. Tsitokiny i vospaleniye. 2017; 16 (3): 3335 (in Russ.)].

8. Дарвин В.В., Онищенко С.В., Краснов Е.А., Васильев В.В., Лысак М.М., Климова Н.В. Острый деструктивный панкреатит: современное хирургическое лечение // Анналы хирургической гепатологии. - 2014. - Т. 19, № 4. - С. 76-82. [Darvin V.V., Onischenko S.V., Krasnov E.A., Vasiliev V.V., Lysak M.M., Klimova N.V. Acute necrotizing pancreatitis: modern surgical treatment. Annaly khirurgicheskoy gepatologii. 2014; 19 (4): 76-82 (in Russ.)].

9. Ильиных Т.Ю., Галян С.Л., Кадочников Д.Ю., Баранов В.Н. Влияние комбинированной анестезии на развитие окислительного стресса эритроцитов в зависимости от режима перфузии при операциях аортокоронарного шунтирования // Вестн. Рос. воен.-медицин. акад. - 2014. - Т. 47, № 3. - С. 45-48. [Ilyinykh T.Yu., Galyan S.L., Kadochnikov D.Yu., Baranov V.N. Influence of combined anesthesia on the development of oxidative stress in erythrocytes depending on mode of perfusion bypass surgery. Vestnik Rossiyskoy voyenno-meditsinskoy akademii. 2014; 47 (3): 45-48 (in Russ.)].

10. Коненков В.И., Рачковская Л.Н., Летягин А.Ю., Суслов Н.И., Шурльгина А.В., Робинсон М.В., Королев М.А., Котлярова А.А., Попова Т.В., Рачков- ский Э.Э., Поветъева Т.Н., Шилова Н.В., Нестерова Ю.В., Афанасъева О.Г., Кульпин П.В. Влияние комплекса лития цитрата, полиметилсилоксана и оксида алюминия на условно-рефлекторное поведение интактных мышей при кофеиновой и алкогольной интоксикации // Российский физиологический журнал им. И.М. Сеченова. - 2017. T. 103, № 10. - C. 1125-1134. [Konenkov V.I., Rachkovskaya L.N., Letjagin A.Yu., Suslov N.I., Shurlugina A.V., Robinson M.V., Korolev M.A., KotlyarovaA.A., Popova T.V., Rachkovsky E.E., Povet'eva T.N., Shilova N.V., Nesterova Yu.V., Afanas'eva O.G., Kul'pin P.V. The influence of the complex of lithium citrate, polymethylsyloxane and aluminum oxide on conditional reflector behavior of intact mice and mice with caffeine and alcohol intoxication. Rossiyskiy fiziologicheskiy zhurnal im. I.M. Sechenova. 2017; 103 (10): 1125-1134 (in Russ.)].

11. Конопля А.И., Бушмина О.Н., Локтионова И.Л., Чуева T.B. Иммуномодуляторы, антиоксиданты, гепатопротекторы при экспериметальном деструктивном остром панкреатите в условиях хронической алкогольной интоксикации // Научные ведомости Белгородского государственного университета. Медицина. Фармация. - 2015. - Т. 31, № 16 (213). - C. 141-148. [Konoplja A.I., Bushmina O.N., Loktionova A.V., Chueva T.V. Immunomodulators, antioxidants, membrane protectors in correction immunometabolic disturbances at the experimental destructive acute pancreatitis in conditions chronic drunkenness. Nauchnyye vedomosti Belgorodskogo gosudarstvennogo universiteta. Meditsina. Farmatsiya. 2015; 31 (16 (213)): 141-148 (in Russ.)].

12. Конопля А.И., Лазаренко В.А., Локтионов А.Л. Взаимосвязь иммунометаболических и эритроцитарных нарушений с этиологией острого панкреатита. - Курск : Изд-во ГОУ ВПО КГМУ Минздрава России, 2013. - 162 с. [Konoplya A.I., Lazarenko V.A., Loktionov A.L. Interrelation of immunometabolic and erythrocyte disorders with etiology of acute pancreatitis. Kursk : Izd-vo GOU VPO KGMU Minzdra-va Rossii; 2013: 162 (in Russ.)].

13. Конопля А.И., Локтионов А.Л., Дудка В.В., Долгарева С.А., Сорокин А.В., Бушмина О.Н. Хроническая интоксикация этанолом: метаболические изменения, коррекция нарушений // Токсикологический вестник. - 2015. - № 5. - С. 25-30. [Konoplya A.I., Loktionov A.L., Dudka V.V., Dolgareva S.A., Sorokin A.V., Bushmina O.N. Chronic intoxication with ethanol: metabolic changes, correction of disturbances. Toksikologicheskiy vestnik. 2015; (5): 25-30. (in Russ.)].

14. Крылов В.И., Виноградов А.Ф., Ефремова С.И. Метод тонкослойной хроматографии липидов мембран эритроцитов // Лаб. дело. - 1984. - № 4. C. 205-206. [Krylov V.I., Vinogradov A.F., Efremova S.I. Thin-layer chromatography of erythrocyte membranes lipids. Laboratornoye delo. 1984; (4): 205-206 (in Russ.)].

15. Летуновский A.B. Метаболические изменения в печени при экспериментальном алкогольном панкреатите и их коррекция // Кубан. науч. медицин. вестн. - 2011. - Т. 6, № 129. - С. 90-94. 
[Letounovski A.V. Metabolic changes in liver at experimental alcoholic pancreatits and their correction. Kubanskiy nauchnyy meditsinskiy vestnik. 2011; 6 (129): 90-94 (in Russ.)].

16. Локтионов А.Л., Конопля А.И., Евсегнеева И.В. Острый панкреатит как клинико-иммунологическая проблема (обзор литературы) // Физиология и патология иммунной системы. Иммунофармакогенетика. - 2013. - Т. 17, № 11. - С. 3-17. [Loktionov A.L., Konoplya A.I., Evsegneyeva I.V. Acute pancreatitis as a clinical and immunological problem (literature review). Fiziologiya i patologiya immunnoy sistemy. Immunofarmakogenetika. 2013; 17 (11): 317 (in Russ.)].

17. Пахомова Р.А., Винник Ю.С., Кочетова Л.В., Нагоров Ю.С. Морфофункциональное состояние эритроцитов при доброкачественной механической желтухе // Вестник хирургии имени И.И. Грекова. - 2017. - Т. 176, № 4. - С. 22-26. DOI:10.24884/0042-4625-2017-176-4-22-26

[Pakhomova R.A., Vinnik Y.S., Kochetova L.V., Nagornov Y.S. Morphofunctional state of erythrocytes in benign obstructive jaundice. Vestnik khirurgii imeni I.I. Grekova. 2017; 176 (4): 22-26 (in Russ.)].

18. Породенко В.А., Травенко Е.В., Быстрова Е.И., Корхмазов В.Т., Ильина А.В. Гистоморфологические исследования в диагностике алкогольных интоксикаций // Кубанский научный медицинский вестник. - 2012. - № 5. - C. 137-140. [Porodenko V.A., Travenko E.N., Bystrova E.I., Korhmazov V.T., Ilyin A.V. Histomorphological studies in the diagnosis alcohol intoxication. Kubanskiy nauchnyy meditsinskiy vestnik. 2012; (5): 137-140 (in Russ.)].

19. Прокопьева В.Д., Ярыгина Е.Г., Коротенко Н.М., Бойко А.С., Бохан Н.А., Иванова С.А. Показатели антиоксидантной системы и дофамина плазмы крови в динамике микроволновой резонансной терапии у больных алкоголизмом // Журнал неврологии и психиатрии им. С.С. Корсакова. - 2017. T. 117, № 9. - C. 67-70. [Prokopieva V.D., Yarygi- na E.G., Krotenko N.M., Boiko A.S., Bokhan N.A., Ivanova S.A. Indices of the antioxidant system and dopamine in blood plasma in the dynamics of microwave resonance therapy in patients with alcoholism. Zhurnal nevrologii i psikhiatrii im. S.S. Korsakova. 2017; 117 (9): 67-70. (in Russ.)].

20. Сазонтова Т.Г., Стряпко Н.В., Архипенко Ю.В. Коррекция нарушений, вызванных длительной алкоголизацией, с помощью гипоксии-гипероксии // Бюл. экспер. биол. и медицины. - 2016. - Т. 162, № 11. - C. 573-577. [Sazontova T.G., Stryapko N.V., Arkhipenko Yu.V. Correction of disorders caused by prolonged alcoholization, with the help of hypoxiahyperoxia. Byulleten' eksperimental'noy biologii i meditsiny. 2016; 162 (11): 573-577 (in Russ.)].

21. Сиволап Ю.П. Связанные с употреблением алкоголя расстройства: новые подходы к диагностике и лечению // Журн. неврологии и психиатрии 2015. - № 9. - C. 23-27. [Sivolap Y.P. Alcohol use disorders: current approaches to diagnosis and treatment. Zhurnal nevrologii i psikhiatrii. 2015; (9): 23-27 (in Russ.)].

22. Шишкина Л.Н., Шевченко О.Г. Липиды эритроцитов крови и их функциональная активность // Успехи современ. биол. - 2010. - Т. 130, № 6. C. 587-602. [Shishkina L.N., Shevchenko O.G. Lipids of blood erythrocytes and their functional activity. Uspekhi sovremennoy biologii. 2010; 130 (6): 587602 (in Russ.)].

23. Dodge G.T., Mitchell C., Hanahan D.J. The preparation and chemical characteristics of hemoglobin free ghosts of human eryrhrocytes // Arch. Biochem. Biophys. - 1963. - Vol. 100. - P. 119-30.

24. Lang F., Qadri S.M. Mechanism and significance eryptosis, the suicidal death of erythrocytes. // Blood Purify. - 2012. - Vol. 33, N 1-3. - P. 125-130. - DOI: $10.1159 / 000334163$.

25. Laemli U.K. Cleavage of structural proteins during the assembly of the head of bacterophage T4 // Nature. 1970. - Vol. 227, N 5259. - P. 680-685. 